\title{
Protein AF1q
}

National Cancer Institute

\section{Source}

National Cancer Institute. Protein AF19. NCI Thesaurus. Code C97389.

Protein AF1q (90 aa, $\sim 10 \mathrm{kDa}$ ) is encoded by the human MLLT11 gene. This protein is involved in the regulation of mitochondrial homeostasis. 